International Journal of English Language and Literature Studies

$\operatorname{ISSN}(e): \quad 2306-0646$

$\operatorname{ISSN}(p): \quad 2306-9910$

DOI: 10.18488/journal.23.2021.102.145.157

Vol. 10, No. 2, 145-157.

(C) 2021 AESS Publications. All Rights Reserved.

URL: wrw.aessweb.com

check for
updates

\title{
SOCIAL INTERACTIONS AS A BARRIER TO SECOND LANGUAGE LEARNING: A SOCIOCULTURAL PERSPECTIVE
}

\author{
Belal Ibrahim \\ Zakarneh $^{1}$ \\ (iD) Najeh Rajeh \\ Alsalhi $^{2+}$ \\ Abdul Raouf Abdulla \\ Bin Talab ${ }^{3}$ \\ Hanaa M. Mansour ${ }^{4}$ \\ Mahmoud Moh'd J \\ Mahmoud $^{5}$
}

\author{
${ }^{1,3,4}$ College of Humanities and Sciences, Ajman University, Ajman, UAE. \\ ${ }^{2}$ College of Humanities and Sciences, Ajman University, Ajman, UAE, \\ Nonlinear Dynamics Research Centre (NDRC), Ajman University, Ajman, \\ UAE. \\ 'Email:nalsalhi@ajman.ac.ae \\ ${ }^{5}$ Foundation Institute, Nizwa University, Oman.
}

The Check for updates

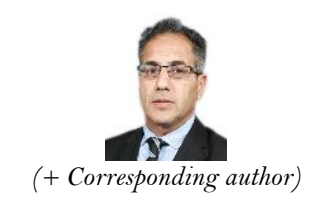

Article History

Received: 26 October 2020 Revised: 19 February 2021

Accepted. 29 March 202

Published: 22 April 2021

\section{Keywords}

Peer interactions

Learners of second language Input and interaction hypothesis

\begin{abstract}
Peer interactions between learners are useful as such interactions have linguistic value to learners of the second language in both academic and non-academic classrooms. However, for learners of the second language, social interaction challenges may impact on their learning and acquisition of the second language. The present study investigates from the sociocultural perspective whether social interactions are barriers to second-language acquisition and education between Arab undergraduates' students of English in Arab universities. The study used the descriptive approach. A questionnaire was distributed to 240 randomly selected learners whose results revealed that sociocultural factors or lack of thereof might serve as a barrier to conversational interactions from the perspective of students. For learners of the second language, attributes like language ego, fear, low self-esteem, aptitude, and low motivation influence their involvement in conversational interactions. As a result, it can be observed how they perceive themselves and how their peers see them in academic classrooms. The results of the study indicate the extent to which social interactions as barriers to second language learning vary according to gender; however, no statistical difference from the point of view of the type of the university was evident in this study. The study recommends further research into the social interactions as barriers to second language learning in higher education institutions.
\end{abstract}

Contribution/ Originality: This study provides a modest addition to the literature about sociocultural perspective examining how social interactions might act as barriers to second-language learning among Arab learners of English in Arab universities. This study also examines whether these social interactions vary according to students' perspective, gender, and university.

\section{INTRODUCTION}

Attention has been drawn to the function of information and interaction in the learning and acquisition of a second language. Some studies suggest that for some learners of English (i.e., native English-speaking environments), social interactions in classrooms serve to promote the acquisition of new linguistic devices/materials from other learners and peers as input and that through this interaction, they produce language. Other studies suggest that for some learners especially those learning in non-English speaking environments, social 
interactions or lack of it thereof serve as a hindrance to their acquisition of new linguistic devices/materials from other learners and peers (Brown, 2008; Liu, 2011; Sato \& Lyster, 2012).

However, there is a consensus among researchers that peer interactions are linguistically beneficial to learners in second language classes. For example, Philip, Adams, and Iwashita (2014) advanced that peer interactions promote learning as it encompasses individuals bringing to the surface personal value systems in the classroom. According to Soliman (2014), learning is likely to take place in classrooms that involve learners engaging in conversational interactions that allow them to share ideas as through these interactions; learners engage more meaningfully. Park and Choi (2009) further acknowledged that oral communication among peers is a classroom activity that promotes participation and involvement of learners in second-language classes, and that through oral communication, learners collaboratively engage in meaning co-construction.

Similarly, Smith (2007) opined that peer conversations and peer discussions in classrooms promote learning and the acquisition of second-language by promoting comprehension achieved when learners share their understandings and discuss learning. According to Schumm (2006) peers may learn from others through the act of articulating their understanding. This view is captured in content learning, where topics that are discussed in peer groups are learned via conversational interactions. Morita (2004) added that in language classes, learners might achieve the two goals through peer interactions: learning content learning and practicing discussion skills. In support of this argument, Ohta (1995) advanced that group interactions in second-language classrooms allow learners to modify and manipulate language to foster the acquisition of language more naturally and understand one another even when learners have different levels of proficiency. Soliman (2014) further noted that group interactions motivate learners in classroom classes to learn from one another by requiring them to utilize "real selfexpression" and greater "self-expression" to accomplish sense.

In the same vein, Sato and Lyster (2012) held that group interactions have psychological and linguistic benefits and argued that they create a positive learning environment for learners which helps them develop a positive selfimage and identity as well as overcome the feelings of inferiority, and this may enable them to perform meaningfully in second-language classrooms. Similarly, Elyas and Picard (2010) stresses the value of peer-mediated instruction and small-group interactions in academic second-language classes by advancing that these activities capacitate learners in becoming competent in communication.

According to Liu (2011), these activities offer opportunities to second-language learners such as written, oral, audial, reading, language acquisition, and development opportunities. Another study conducted by Wang and Castro (2010) within the Chinese context reported that peer interactions in English Language classrooms help learners notice the target form and acquire language forms. For Fang (2010) classroom interactions can positively affect the facilitation and development of second-language learning by setting the learning education, and enabling learners to consider form-focused feedback. In a similar study, Loewen and Basturkmen (2005) analyzed interactions in English as a foreign Language classroom. They concluded that students paid attention to discourse and language form when engaging in interactions with peers. Loewen and Basturkmen (2005) observed that learners could experiment with language in activities involving peer interactions. Supporting this view, Philip et al. (2014) observed that in second-language classrooms, interference with language might happen via learners patronizing to the form, providing an additional form or correcting form according to the activity that takes place in a classroom.

According to Philip et al. (2014), through working together, learners can provide their individuals intellectual resources into the discussion and the task at hand, as well as use different alternatives to achieve their objectives. For other studies like (Lee, 2015; Morita, 2004), when learners collaborate through interactions, they assist each other and develop better control of language. Other researchers have shown that a learner's conversational skill in a foreign language or lack of it minimizes or maximizes the possibilities for interactions in higher education settings and academic classrooms (Park \& Choi, 2009; Tatar, 2005). These studies show that participating in oral activities 
in a classroom, and interacting with proficient peers (e.g., in whole-class discussions, small-groups, pairs) challenges faced by non-native English learners and that this compromises their learning experience in foreign language classrooms. According to the study conducted by Dongyu, Fanyu, and Wanyi (2013) assert that the way of learning and teaching and teacher-student relationship should be changed in order to implement collaborative learning. It is, however, unclear whether these social interactions are barriers to second-language acquisition among Arab learners of English in higher education.

The present study investigates from the sociocultural perspective whether social interactions are barriers to second-language learning among Arab learners of English in Arab universities.

\subsection{Significance of Interactions in the Acquisition of Second-Language}

As described by Philip et al. (2014), peer interactions are communicative activities occurring between learners that involve minimal involvement of a teacher. These interactions may involve multiple participants working collaboratively to achieve a common goal: learning. Communicative activities that require individuals to work collaboratively tend to vary in nature. Examples of these activities in language classrooms include peer modeling, peer tutoring, cooperative learning, and collaborative learning where collaborative learning requires learners to work together and show a sense of mutuality jointly. Cooperative learning takes the form of collaborative learning. However, the level or degree of mutuality in cooperative learning differs from that of collaborative learning (Philip et al., 2014). Peer tutoring involves more proficient participants assisting lower proficient participants to achieve the desired learning goal.

Studies on second-language acquisition suggest that for learners to properly acquire socio-linguistic and linguistic rules, the learning environment must offer opportunities that allow learners and users to engage in meaningful social interactions (Long, 1996; Packer \& Goicoechea, 2000). As advanced by Lantolf and Beckett (2009) the social interaction that appropriately facilitates the language development is that which facilitates language students and their interlocutors to express a desire and need to comprehend and learn one another. For Turuk (2008) for learners to successfully comprehend the second language, they should restructure their interactions and conversations and use their mutual desire to understand each other to achieve the goal of learning/acquiring language.

In furtherance of this argument, Long (1996) observed that a conversation may be restructured through checks, confirmation, and requests for clarification about the comprehensibility of language among speakers. On a similar argument, Packer and Goicoechea (2000) pointed out that the learning environment provides learners with opportunities to modify restructured and modified conversational exchanges and as a result, naturalistically promote second-language acquisition, where these situations arise when learners who engage in grammatical interplay have a responsibility to share and request information that peers want. Swain and Deters (2007) added that learners engaged in conversational interaction often recognize their differences in language proficiency and modify and restructure their language accordingly.

Lee (2015) also believes that communicative interaction among native speakers and non-native speakers of a language facilitates learners to comprehend unfamiliar material. Mori (2014) argued that conversational interaction allows both speakers to utilize restructured and modified language, thereby making the meaning of discursive exchanges during their interactions. Lee (2015) further opined that during such interactions, native speakers assist learners of the second language in understanding new linguistic material and in better expressing themselves as well as receive meaning in the second language. In this light, Tatar (2005) argued that conversational peer interactions are useful as they have linguistic significance to learners of the second language in both the academic and non-academic classrooms.

For some researchers, learning is achieved through social interaction. These proponents of sociocultural theoretical consider the learning process as one that can be achieved both socially and individually. Sociocultural 
theory, as proposed by Vygotsky, suggests that language learners mediate human mental activity and articulate and transform their thinking (Lantolf \& Thorne, 2007). According to Swain and Deters (2007), sociocultural theory deviates from the focus on an individual as reflected in the traditional approaches. It focuses on the contribution of sociocultural and interaction context towards the comprehension and construction of meaning. In view of sociocultural theory to language learning, language is a constituent of thought and contributes to cognitive development. According to this theory, learners' cognitive activities are developed through language use (Lantolf \& Thorne, 2006; Swain \& Deters, 2007).

As indicated by Lantolf and Thorne (2006) the central concept in Vygotsky's sociocultural theory is the Zone of Proximal Development (ZPD). ZPD is believed to take into consideration the cognitive development and social interaction to explain how learners engage in a learning activity with the assistance of more competent others (i.e., peers and teachers) (Kinginger, 2009). As explained by Swain, Brooks, and Tocalli-Beller (2002) the concept behind ZPD is that learning is achieved when learners interact with peers of a higher or same level of competency. Swain et al. (2002) further observed that this social interaction construct is seen as a space that provides the potential for transformations of learner's identity of activity setting a culture's toolkit rather than as an attribute of settings or learners themselves. In view of the sociocultural perspective, language development may occur when learners participate in interactions in cultural, historical, and linguistically-formed settings (e.g., conversational peer interactions occurring in the academic classroom). The argument is that during peer conversational interactions, learners of the second language may acquire language by imitating the context-specific language of their peers and re-use it to interpret their social interactions (Liu, 2015).

\subsection{Social Interactions as a Barrier to Second-Language Learning: Past Studies}

Several studies conducted with western countries have suggested that students of the second language both locally and abroad often experience social interaction challenges in foreign language classrooms and that this experience may impact their second language acquisition (Chen \& Jiang, 2004; Kim, 2006; Leki, 2001; Liu, 2001; Pawanchik, Kamil, Hilmi, \& Baten, 2011 ; Wright \& Lander, 2003). In a survey involving 70 international students studying in a U.S. university from East Asia, Kim (2006) explored the perceptions of learning with regard to the necessary academic interactions (i.e., level of speaking and listening skills) and challenges experienced in an attempt to meet these expectations. In view of this study, the most common activities identified by learners as taking place in academic classrooms were engaging in group discussions, raising questions during class, and participating in whole-class discussions.

The issues of concern to learners of the second language were noted as leading class discussions and engaging in whole-class discussions. For these learners, these two issues were a major challenge on the grounds that these required them to be proficient in the language in order to take part in classroom oral activities actively. For these learners, lower proficiency in speaking the English language in front of instructors and peers, low linguistic capacity, and subject-specific knowledge in the classroom environment was stressful and intimidating events as they were obstacles to their participation in classroom interactions. The finding of Kim (2006) study also, suggests that international learners of the second language are hindered from actively participating in oral activities in academic classrooms because of the inadequate knowledge of the content of the subject being taught and academic English.

These results were replicated in the studies by Leki (2001) and Liu (2001). These studies reported that the interacting conversationally with peers and the level of pedagogical discourse expected and use in content-specific language classes is a challenge for learners of English as second language. These authors also noted that a learner expresses feelings of frustration and inadequacy when making attempts to engage in classroom activities.

Wright and Lander (2003) investigated differences in verbal interaction rates during learners' collaborative group activity using undergraduate Anglo-European learners, foreign-born South Asian studying English as second language, and Australian-born students of the second language in Australian university. This study 
measured how learners worked in bi-ethnic groups and mono-ethnic groups on a problem-solving task. Results confirmed that learners from South East Asian were inhibited in verbal interaction when with students in Australia. Both South East Asian and Australian learners in the bi-ethnic groups produced fewer verbal interactions compared to those in mono-ethnic groups. However, learners of the second language had a significantly larger difference in verbal productions than native-English speakers. The insight from this study was that South East Asian learners of second language were impacted more by their interaction in bi-ethnic groups that native-speaker Australian learners. On the basis of this result, the authors advanced that language proficiency, and the mode of operation of Australian students account for the differences in number of verbal productions in mono-ethnic groups and that the dominance of the native speakers' mode of operation during the conversational interactions enable them to be more confident and comfortable in the discussion as it was their local social-academic setting.

In a survey administered to international learners of the second language at the New Zealand's University of Otago, Pawanchik et al. (2011) investigated the perception of learners towards what they considered the most important skill needed for one to be successful in academic studies. The study results showed that international learners of the second language consider speaking skills as the most important skill needed to participate in conversations with peers in classrooms. Students reported that they hardly participate in class discussions because of shyness and being passive and that these two stemmed from fear to consult with peers and fearing making mistakes.

In a 12-month-long ethnographic study involving international students at South England's university, Brown (2008) found that second language learners often experience an extreme level of anxiety because of their low level of proficiency in second language. The majority of learners of second language experienced feelings of shame and inferiority. These learners also reported challenges of academic writing and reading with their greatest anxiety originating from their inability to write and communicate orally with ease and with confidence in face-to-face engagement with their peers.

In a case study undertaken at a higher education institution in the U.S., Wu, Garza, and Guzman (2015) interviewed international learners of second language, both graduate and undergraduate with a view to understanding the academic challenges encountered by these learners and their adjustment strategies. The study noted that inadequate language proficiency serves as a barrier to the academic success of second language learners. Some learners reported being left out in conversational interactions during group work because of their difficulty in following their peers' conversational exchanges. These participants felt that their identity was challenged as peers would not let them join the conversation and the group. The researchers advanced that the key challenge to second language learners is the difficulty in communicating orally within academic settings.

\subsection{Study Questions}

The study responds to two research questions:

RQ1: To what extent are social interactions act as barriers to the acquisition of second-language learning among Arab learners of English in Arab universities?

RQ2: Does the extent of social interactions as barriers to acquisition and learning of second-language among Arab learners of English in Arab universities vary based on students' perspective, gender, and university?

\section{METHODOLOGY}

\subsection{Study Participants}

The current study's participants consisted of 240 learners of foreign language conveniently selected from four universities in different countries in the Arab World. Only participants with Arabic as their first language and enrolled in foreign language classes were selected. In this context, foreign language was limited to English meaning all participants were second learners of English studying in a university within the Arab World. The study was 
conducted throughout the 1st term of the 2019/2020 university year. Table 1 and Figures 1, 2 show the study participants' demographic information.

Table-1. participants' demographic Information.

\begin{tabular}{l|l|c|c}
\hline \multicolumn{3}{c}{ Table-1. participants' demographic Information. } \\
\hline \multirow{3}{*}{ Gender } & & $\mathbf{N}$ & $\mathbf{\%}$ \\
\hline \multirow{4}{*}{ University } & Female & 125 & $52 \%$ \\
\cline { 2 - 4 } & Male & 115 & $48 \%$ \\
\cline { 2 - 4 } & Total & 240 & $100 \%$ \\
\hline & Ajman University, UAE & 85 & $35 \%$ \\
\cline { 2 - 4 } & Yarmouk University, Jordan & 55 & $23 \%$ \\
\cline { 2 - 4 } & Omdurman University, Sudan & 48 & $20 \%$ \\
\cline { 2 - 4 } & Damascus University, Syria & 52 & $22 \%$ \\
\cline { 2 - 4 } & Total & 240 & $100 \%$ \\
\hline
\end{tabular}

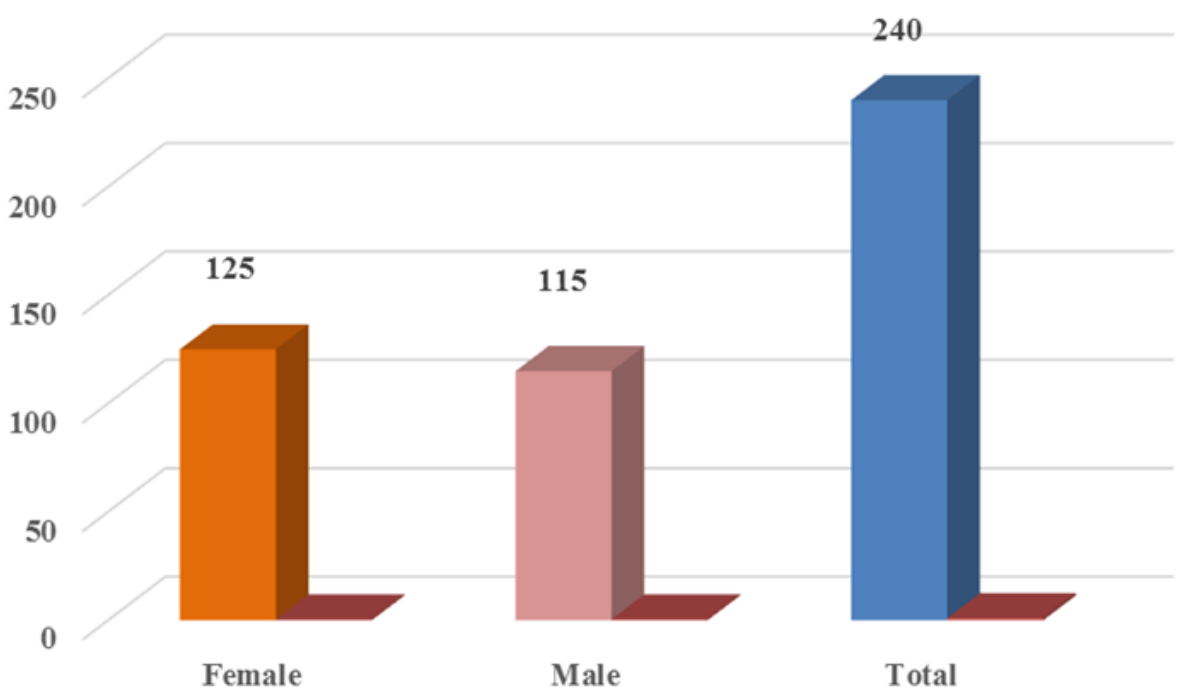

Figure-1. Percentage distribution of study participants based on their Gender.

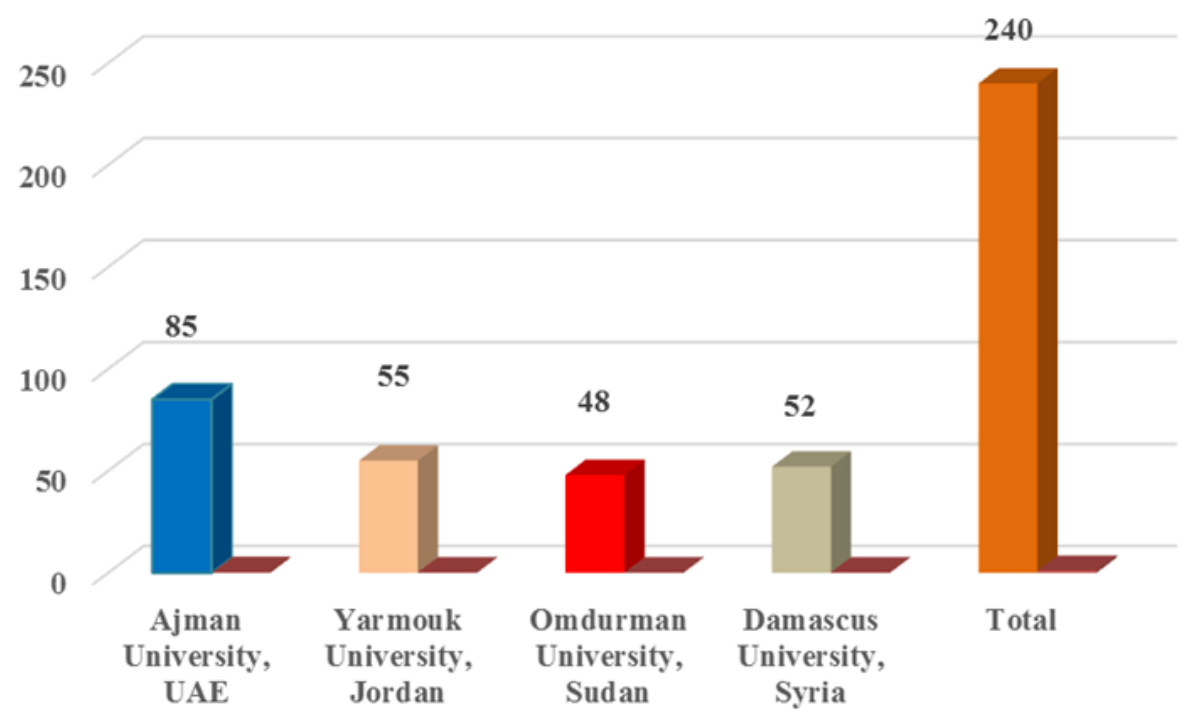

Figure-2. Percentage of Participants ' according to University.

\subsection{Study Data Collection Instrument}

In the present study, a survey questionnaire served as a tool for collecting data from study participants. Accordingly, a survey questionnaire was designed and distributed via email to learners of second-language in Arab universities within the Arab world. It was divided into two parts with the first part consisting of questions focusing 
on participants' background information and the second part consisting of questions that focused on social interactions and second-language acquisition.

\subsection{Validity and Reliability of the Survey Questionnaire}

The researcher assessed the questionnaire's validity using virtual validity method. Using this method, the researcher assessed the content validity by involving a team of arbitrators. In this way, experts in the field of teaching methods of English and Sociology expressed their opinions regarding the content of the questionnaire. These experts assessed the suitability of the items in meeting the aims of the study and its overall purpose. Reliability of the questionnaire was assessed using a pilot study involving 30 learners and measured the Cronbach's alpha coefficient of Cronbach using the SPSS (0.892).

\subsection{Data Analysis Measures}

The questionnaire contained questions rated on the 5 -point Likert Scale with 5 denoting very high, 4 denoting high, 3 denoting moderately high, 2 denoting low and 1 denoting very low. Responses to study questions were categorized as reflected in Table 2 :

Table-2. The choices of scale and score periods of Likert scale.

\begin{tabular}{c|c|c}
\hline Choices & Evaluation & Evaluation periods \\
\hline Very high & 5 & $4.21-5.00$ \\
\hline High & 4 & $3.41-4.20$ \\
\hline Moderate & 3 & $2.61-3.40$ \\
\hline Low & 2 & $1.81-2.60$ \\
\hline Very low & 1 & $1.00-1.80$ \\
\hline
\end{tabular}

\subsection{Compilation of Data and Statistical Analysis}

Statistical analysis was carried using version 26 of the SPSS to obtain descriptive statistics: standard deviation, mean and percentage. SPSS was also used to perform independent tests of t-test, Scheffe test, and one-way analysis of variance (ANOVA)

\section{FINDINGS}

\subsection{Research Question 1: Study Findings}

As noted herein, first research question concerned the extent to which social interactions act as barriers to the acquisition of second-language learning among Arab learners of English in Arab universities. In an attempt to respond to this research question, descriptive statistics notably standard deviations and mean scores of study participants' responses to each of the questionnaire Items 1-20 were calculated, as seen in Table 3.

Based on the findings shown in Table 3 and Figure 3, the overall mean and SD of 20 items listed on the questionnaire items were 3.50 and 0.94 respectively. This value indicates that students highly view the social interactions as barriers to second-language learning. In the same vein, as shown in Table 3, students highly agree (mean-4.29) to the statement: "I rarely engage in whole-class discussions or raise questions in class". Students also feel incompetent in English language as their response to Item 2 ("I feel incompetent in English language") indicated as such. This item was rated as having the second highest level of agreement, with an average of (4.21). Item 3 ("I have problems speaking proficiently in English in conversations with my peers and professor in classroom") with a mean of 3.81 had the third highest level of agreement suggesting that majority of students have challenges speaking proficiently in English in conversations with their peers and professor in classroom. Item 4 ("I have a low linguistic capacity and subject-specific knowledge while in classroom environment”) had a mean of 3.75 ranked as the fourth item with the highest level of agreement. This indicates that students highly students agree that they have a low linguistic capacity and subject-specific knowledge while in classroom environment. Equally, 
item 5 ("My low linguistic capacity and subject-specific knowledge stress and intimidate me and prevent me from participating in classroom interactions") with the mean of 3.70 affects students. As it suggests that participants highly agree that students' low linguistic capacity and subject-specific knowledge stress that serves to intimidate them preventing them from participating in classroom interactions.

Similarly, a "High" level was also found for Items 6, 7, 8, 9, 10, 11, and 12, with the respective average values of 3.65, 3.57, 3.52, 3.48, 3.48, 3.44 and 3.42. The lowest average (3.05) was obtained for Item 20 ("As I try to speak English in the schools, I still feel frustrated and mocked.”) indicating a moderate degree of use. Other items were moderate degree of agreement based on participants' responses include items 13, 14, 15, 16, 17, 18, and 19, with the respective average values of 3.40, 3.35, 3.33, 3.21, 3.15, 3.08, and 3.06.

Table-3. Mean and Standard Deviation (SD) of responses towards items linking social interactions are barriers to second-language learning.

\begin{tabular}{|c|c|c|c|c|}
\hline No & Paragraphs & Mean & SD & Description \\
\hline 1 & $\begin{array}{l}\text { I rarely engage in whole-class discussions or raise questions in } \\
\text { class }\end{array}$ & 4.29 & 0.73 & Very High \\
\hline 2 & I feel incompetent in English language & 4.21 & 0.96 & Very High \\
\hline 3 & $\begin{array}{l}\text { I have problems speaking proficiently in English in conversations } \\
\text { with my peers and professor in classroom }\end{array}$ & 3.81 & 0.98 & High \\
\hline 4 & $\begin{array}{l}\text { I have a low linguistic capacity and subject-specific knowledge } \\
\text { while in classroom environment }\end{array}$ & 3.75 & 0.95 & High \\
\hline 5 & $\begin{array}{l}\text { My low linguistic capacity and subject-specific knowledge stress } \\
\text { and intimidate me and prevent me from participating in } \\
\text { classroom interactions }\end{array}$ & 3.70 & 0.97 & High \\
\hline 6 & $\begin{array}{l}\text { I feel frustrated and inadequate whenever I attempt to engage in } \\
\text { classroom conversational activities }\end{array}$ & 3.65 & 0.96 & High \\
\hline 7 & I am always shy and passive in classroom interactions & 3.57 & 0.95 & High \\
\hline 8 & I found oral involvement an useful part of English learning. & 3.52 & 0.90 & High \\
\hline 9 & $\begin{array}{l}\text { I experience feelings of shame and inferiority while in English } \\
\text { classroom }\end{array}$ & 3.48 & 0.98 & High \\
\hline 10 & I have a challenge of academic writing and reading & 3.48 & 0.94 & High \\
\hline 11 & $\begin{array}{l}\text { I am always anxious to participate in conversational interactions } \\
\text { because of my inability to write and interact oral with ease and } \\
\text { with confidence in face-to-face engagement with their peers }\end{array}$ & 3.44 & 0.96 & High \\
\hline 12 & $\begin{array}{l}\text { My fear my identity would be challenged as peers would not let } \\
\text { me join the conversation and the group }\end{array}$ & 3.42 & 0.94 & High \\
\hline 13 & $\begin{array}{l}\text { My fear my identity would be challenged as peers would not let } \\
\text { me join the conversation and the group }\end{array}$ & 3.40 & 1.15 & Moderate \\
\hline 14 & I remain very hesitant to learn English & 3.35 & 0.96 & Moderate \\
\hline 15 & It's hard for me to dispose of my first language accent & 3.33 & 0.97 & Moderate \\
\hline 16 & I guess I'm very bad at learning the language & 3.21 & 0.87 & Moderate \\
\hline 17 & I'm always afraid to make mistakes when I speak English & 3.15 & 0.90 & Moderate \\
\hline 18 & $\begin{array}{l}\text { My ability to learn the English language is probably relatively } \\
\text { poor }\end{array}$ & 3.08 & 0.98 & Moderate \\
\hline 19 & I don't have the ability to learn English skills & 3.06 & 1.05 & Moderate \\
\hline 20 & $\begin{array}{l}\text { As I try to speak English in the schools, I still feel frustrated and } \\
\text { mocked. }\end{array}$ & 3.05 & 0.73 & Moderate \\
\hline \multicolumn{2}{|c|}{ Total (Average) } & 3.50 & 0.94 & High \\
\hline
\end{tabular}




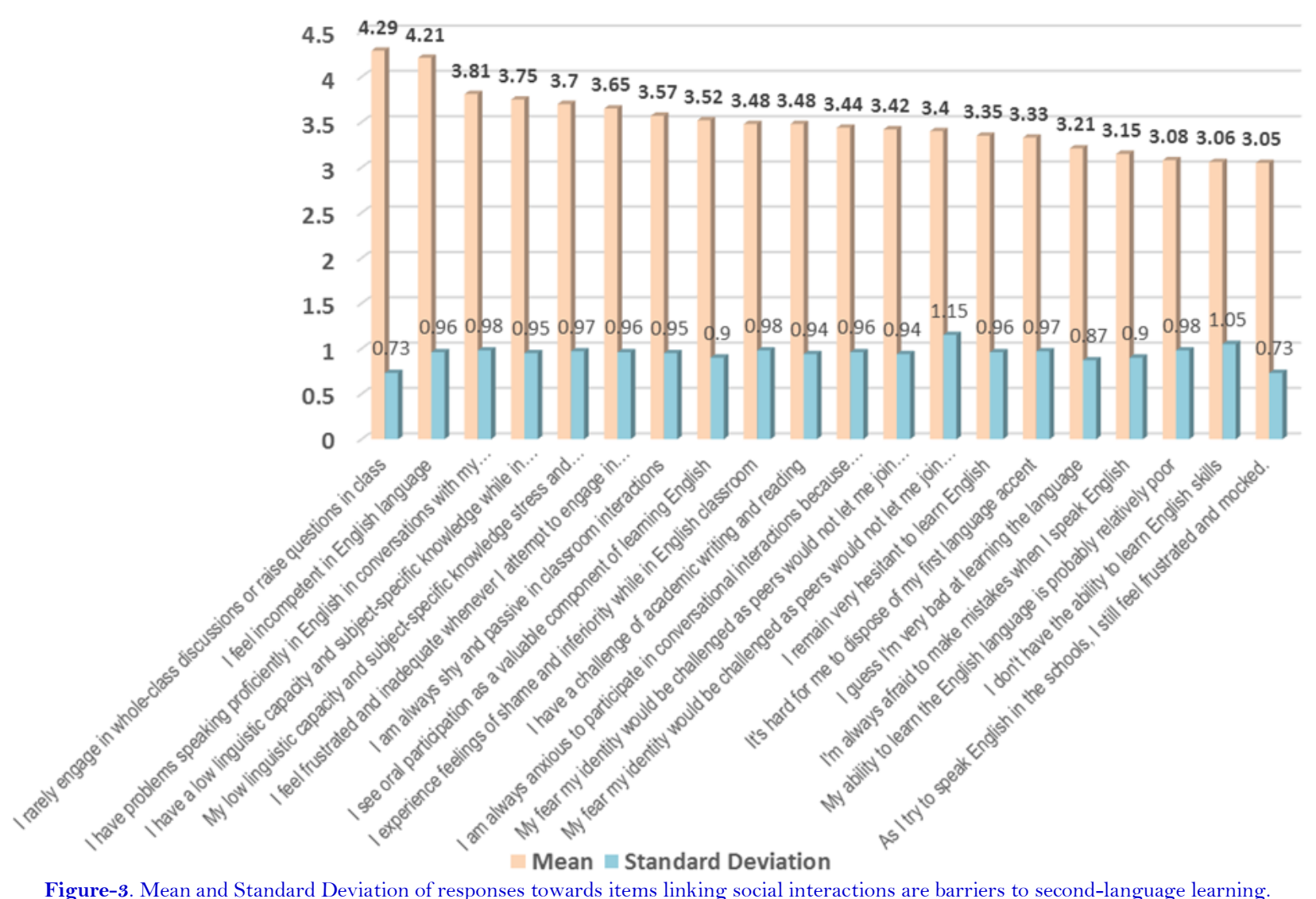

\subsection{Question 2: Study Findings}

The second question concerned the extent to which social interactions act as possible barriers to secondlanguage learning among Arab learners of English in Arab universities, wherein the variance was based on students' perspective, Gender, or University. This question was responded by calculating the means scores and SD of the responses to items relating to this question. Further, significant difference between means was determined from independent t-test and variance test. One-way ANOVA was used to assess the significance difference between universities and different genders. Table 4 and Table 5 provide t-test results for the students' responses based on their gender and university.

\subsection{First: Gender}

Differences in participants' perspective based on gender with regard to social interactions as barriers to secondlanguage acquisition was assessed using independent sample test $(T)$ as shown in Table 4.

Table-4. Means and SD of participants' responses to items in questionnaire based on their gender.

\begin{tabular}{c|c|c|c|c|c}
\multicolumn{6}{c}{ Table-4. Means and SD of participants' } \\
\cline { 1 - 3 } Gender & N & Mean & SD & T. Value & Sig. (tailed) \\
\hline Male & 115 & 3.65 & 0.69 & 2.488 & \multirow{2}{*}{$0.014^{*}$} \\
\cline { 1 - 2 } Female & 125 & 3.39 & 0.93 & & \\
\hline
\end{tabular}

As can be inferred from Table 4, the computed t-value of 2.488 is greater than the (t-table), suggesting that men and females significantly differ $(\mathrm{p}=0.014$, which is less than the required statistical significance level (0.05) in perspective towards social interactions as barriers to second-language acquisition. 
3.4. Second: University

Similarly, differences in participants' perspective based on university with regard to social interactions as barriers to second-language acquisition were assessed using ANOVA as shown in Table 5.

Table-5. One-way ANOVA based on the "University".

\begin{tabular}{|c|c|c|c|c|c|c|}
\hline & & Sum of squares & df & Mean square & $\mathbf{F}$ & Sig. (tailed) \\
\hline \multirow{3}{*}{ University } & Between Groups & 1.301 & 3 & 0.434 & \multirow{3}{*}{0.630} & \multirow{3}{*}{0.596} \\
\hline & Within Groups & 162.398 & 236 & 0.688 & & \\
\hline & Total & 163.699 & 239 & & & \\
\hline
\end{tabular}

As can be inferred from Table 5, students do not differ significantly ( $\mathrm{p}=0.596$ greater than 0.05 ) in perspectives based on their universities with regard to social interactions as barriers to second-language acquisition

\section{DISCUSSION}

This study investigated whether social interactions are barriers to second-language learning among Arab students of English in Arab universities. Based on the finding of the study, students consider social interactions as barriers to second-language learning for Arab learners of English in Arab universities as students highly approve the items identifies interactions as barriers to second-language acquisition. In view of these study findings, sociocultural factors like history, culture, legacy, behavior, etc. may serve as a hindrance to conversational interactions. As revealed herein language the psychological and emotional factors like ego, fear, low self-esteem, aptitude, and low motivation may affect second learners' participation in conversational interactions, and consequently how they perceive themselves and how their peers perceive them in academic classrooms. Secondlanguage learners noted that they rarely engage in whole-class discussions or raise questions in class; feel incompetent; have problems speaking proficiently in English in conversations with their peers and professor in classroom; have low linguistic capacity and subject-specific knowledge which causes them stress, intimidate them and prevent them from actively participating in classroom interactions.

These factors also make them feel frustrated and inadequate whenever they attempt to engage in classroom conversational activities; make them feel shy and passive in classroom interactions; fear to consult with peers and making mistakes; feel shameful and inferior while in English classroom. In addition, these second-learners of language find of academic writing and reading challenging; feel anxious to participate in conversational interactions because of inability to write and interact orally with ease and with confidence in face-to-face engagement with their counterparts; and feel that their identity would be challenged as peers would not let them join the conversation and the group.

However, it is worth noting is that learners of second language consider oral participation as a valuable component of learning English. This reflects the view by Zakarneh (2018) that sociocultural factors contribute to language ego in learners of second language and that ego makes these learners frightened in learning the second language, these sociocultural factors make learners of the second language frightened when attempting to speak the second language; they are concerned about forms-mistakes while attempting to communicate spontaneously with peers in second language classrooms. These inhibitions are believed to serve as a defense for the ego. This language ego is also thought to cause increased fear of committing mistakes in academic classrooms making it difficult for learners of second language to engage in conversational discussions. In this way, for these learners, sociocultural factors are believed to serve as internal and external hindrances to their active participation in classroom conversations. Turuk (2008) further confirmed that the perception of incompetent in second language by a learner in the foreign language classroom might affect his/her identity consequently affecting his/her interpersonal and intrapersonal experiences. This perception may require the learner to make attempts to negotiate their membership, expertise, and identity through interactions with peers and instructors in the classroom. 
The present study also noted that some learners of the second language in the Arab World universities consider themselves as not pertinent members of the second language schoolroom group as they consider themselves as having insufficient linguistic abilities. For these learners, insufficient linguistic abilities deny them the opportunity to access the identity of competent language members of the second language classroom context. In this context, these learners construct competence around language proficiency seeing their peers as possessing higher language skill than them. These perceptions influenced these learners into considering themselves as inferior and unable to actively participate in classroom interactions.

This study results further demonstrate how cultural issues and educational issues compounded with insufficient language skills for oral classroom discussions may serve as impediments to second language learners' successful adaptation into foreign language classroom context. Though these learners see oral participation in classroom as valuable to learning language and put in effort to meet these learning objectives, they are concerned about sounding intelligent and competent in a foreign language when engaging and interacting with their peers who appear proficient in foreign language. This feeling of inefficiency makes these learners to experience frustrations, anxiety and fear. This view is supported by finding by Brooks (2009) that for majority of learners of second language, classroom participation is considered a complex process.

This view was also reflected in Liu (2011) that Chinese undergraduates transitioning to university from secondary school in Canada reported feeling anxious, confused and frustrated when in second language classrooms. These fears and frustrations were attributed to their lack of academic language skills or insufficient linguistic abilities and that this affected their integration into foreign language classroom community. Moreover, the obtained results, as shown in Table 4, and 5 related to whether the extent of social interactions as barriers to second language learning among Arab learners of English in Arab universities varies based on learners' perspective, gender, and University. The results reveal that the extent of social interactions as barriers to second language learning among Arab learners of English in Arab universities from the students' perspective varies according to gender (in favor of the Males students), and depending on University type.

\section{CONCLUSION}

The results of this study display that social interactions may serve as barriers to second-language learning as demonstrated herein from the point of view of Arab learners of English in Arab universities. These include learners' insufficient academic language skills, low self-esteem, aptitude, and low motivation and language ego may impact their involvement in conversational interactions, and therefore how they view themselves and how their peers perceive them in educational classrooms. Moreover, the results indicate that the extent of social interactions as barriers to second language learning among Arab learners of English in Arab universities from the students' perspective varies according to gender, and depending on University type.

\subsection{Pedagogical Implications}

It is paramount that teachers of foreign language understand factors that hinder learners from engaging in classroom interactions in higher institutions. By doing so, they can provide the necessary support to learners of second language to enable them develop into active participants in conversational interactions. Instructors can achieve this by helping these learners overcome complex sociocultural barriers history, culture, legacy, behavior, etc and psychological factors like language ego, fears, lack of motivation in order for these learners to successfully acquire foreign language. Accordingly, teaching methods adopted by instructors should be one that help these learners overcome these barriers rather than reinforce them.

Funding: This study received no specific financial support.

Competing Interests: The authors declare that they have no competing interests.

Acknowledgement: All authors contributed equally to the conception and design of the study. 


\section{REFERENCES}

Brooks, A. K. (2009). Complexity and community: Finding what works in workplace ESL. New Directions for Adult and Continuing Education, 2009(121), 65-74. Available at: https://doi.org/10.1002/ace.326.

Brown, L. (2008). Language and anxiety: An ethnographic study of international postgraduate students. Evaluation and Research in Education, 21(2), 75-95.

Chen, F.-C., \& Jiang, H.-M. (2004). Exploration of peer-facilitator dynamics in two contrasting groups. Instructional Science, 32(6), 419-446. Available at: https://doi.org/10.1007/s1 1251-004-2275-7.

Dongyu, Z., Fanyu, B., \& Wanyi, D. (2013). Sociocultural theory applied to second language learning: Collaborative learning with reference to the Chinese context. International Education Studies, 6(9), 165- 174. Available at: https://doi.org/10.5539/ies.v6n9p165.

Elyas, T., \& Picard, M. (2010). Saudi Arabian educational history: Impacts on English language teaching. Education, Business and Society: Contemporary Middle Eastern Issues, 3(2), 136-145.

Fang, X. (2010). The role of input and interaction in second language acquisition. Cross-Cultural Communication, 6(1), 11-17.

Kim, S. (2006). Academic oral communication needs of East Asian international graduate students in non-science and nonengineering fields. English for Specific Purposes, 25(4), 479-489. Available at: https://doi.org/10.1016/j.esp.2005.10.001.

Kinginger, C. (2009). Language learning and study abroad: A critical reading of research. Basingstoke, UK: Palgrave Macmillan.

Lantolf, J. P., \& Thorne, S. L. (2006). Sociocultural theory and the genesis of second language development. Oxford: Oxford University Press.

Lantolf, J. P., \& Beckett, T. G. (2009). Sociocultural theory and second language acquisition. Language Teaching, 42(4), 459-475. Available at: https://doi.org/10.1017/So26 1444809990048.

Lantolf, J., \& Thorne, S. L. (2007). Sociocultural theory and second language learning. In. B. van Patten \& J. Williams (Eds.), Theories in Second Language Acquisition (pp. 201-224). Mahwah, NJ: Lawrence Erlbaum.

Lee, M. S. (2015). Implementing the sociocultural theory while teaching ESL. SPACE: Student Perspectives About civic Engagement, $1(1), 28-35$.

Leki, I. (2001). "A narrow thinking system”: Nonnative-English-speaking students in group projects across the curriculum. TESOL Quarterly, 35(1), 39-67.

Liu, J. (2001). Asian students' classroom communication patterns in U.S. universities: An emic perspective. Westport, CT: Ablex.

Liu, L. (2011). An international graduate student's ESL learning experience beyond the classroom. TESL Canada Journal, 29(1), $77-92$.

Liu.., D. (2015). A critical review of Krashen's input hypothesis: Three major arguments. Journal of Education and Human Development, 4(4), 139-146.

Loewen, S., \& Basturkmen, H. (2005). Interaction in group writing tasks in genre-based instruction in an EAP classroom. Journal of Asian Pacific Communication, 15(1), 171-189. Available at: https://doi.org/10.1075/japc.15.1.11loe.

Long, M. (1996). The role of the linguistic environment in second language acquisition. In Ritchie, W. C., \& Bhatia, T. K. (Eds.), Handbook of second language acquisition (pp. 413-468). New York: Academic Press.

Mori, M. (2014). Conflicting ideologies and language policy in adult ESL: Complexities of language socialization in a majorityL1 classroom. Journal of Language, Identity $\Xi$ Education, 13(3), 153-170. Available at: https://doi.org/10.1080/15348458.2014.919810.

Morita, N. (2004). Negotiating participation and identity in second language academic communities. TESOL Quarterly, 38(4), 573-603.

Ohta, A. S. (1995). Applying sociocultural theory to an analysis of learner discourse: Learner-learner collaborative interaction in the zone of proximal development. Issues in Applied Linguistics, 6(2), 93-121.

Packer, M. J., \& Goicoechea, J. (2000). Sociocultural and constructivist theories of learning: Ontology, not just epistemology. Educational Psychologist, 35(4), 227-241. Available at: https://doi.org/10.1207/s15326985ep3504_02. 
Park, J.-H., \& Choi, H. J. (2009). Factors influencing adult learners' decision to drop out or persist in online learning. Journal of Educational Technology \& Society, 12(4), 207-217.

Pawanchik, S., Kamil, A. A., Hilmi, M. F., \& Baten, M. A. (2011). English language needs of non-native foreign students. SinoUS English Teaching, 8(8), 505-510.

Philip, J., Adams, R., \& Iwashita, N. (2014). Peer interaction and second language learning. New York: Routledge.

Sato, M., \& Lyster, R. (2012). Peer interaction and corrective feedback for accuracy and fluency development: Monitoring, practice, and proceduralization. Studies in Second Language Acquisition, 34(4), 591-626. Available at: https://doi.org/10.1017/s0272263112000356.

Schumm, J. S. (2006). Reading assessment and instruction for all learners. New York: Guilford Press.

Smith, H. J. (2007). The social and private worlds of speech: Speech for Inter-and intramental activity. The Modern Language Journal, 91(3), 341-356. Available at: https://doi.org/10.1111/j.1540-4781.2007.00584.x.

Soliman, T. (2014). Learning English in Saudi Arabia: A socio-cultural perspective. International Journal of English Language and Linguistics Research, 2(3), 56-78.

Swain, M., Brooks, L., \& Tocalli-Beller, A. (2002). 9. Peer-Peer dialogue as a means of second language. Annual Review of Applied Linguistics, 22, 171-185. Available at: https://doi.org/10.1017/s0267190502000090.

Swain, M., \& Deters, P. (2007). "New" mainstream SLA theory: Expanded and enriched. The Modern Language Journal, 91, 820836. Available at: https://doi.org/10.1111/j.0026-7902.2007.00671.x.

Tatar, S. (2005). Classroom participation by international students: The case of Turkish graduate students. Journal of Studies in International Education, 9(4), 337-355. Available at: https://doi.org/10.1177/1028315305280967.

Turuk, M. C. (2008). The relevance and implications of Vygotsky's sociocultural theory in the second language classroom. Arecls, 5(1), 244-262.

Wang, Q., \& Castro, C. D. (2010). Classroom Interaction and Language Output. English Language Teaching, 3(2), $175-186$.

Wright, S., \& Lander, D. (2003). Collaborative group interactions of students from two ethnic backgrounds. Higher Education Research \& Development, 22(3), 237-251. Available at: 10.1080/0729436032000145121.

Wu, H.-P., Garza, E., \& Guzman, N. (2015). International student's challenge and adjustment to college. Education Research International, 2015, 1-9.

Zakarneh, B. (2018). Language ego as a barrier in English language acquisition among Arab university students. British Journal of English Linguistics, 6(3), 40-55.

Views and opinions expressed in this article are the views and opinions of the author(s), International Journal of English Language and Literature Studies shall not be responsible or answerable for any loss, damage or liability etc. caused in relation to/arising out of the use of the content. 